\title{
Sustainability of TQM Implementation Model In The Indonesia's Oil and Gas Industry: An Assessment of Structural Relations Model Fit
}

\author{
Wakhid Slamet Ciptono \\ Alumnus Graduate School of Business, Faculty of Business and Accountancy, University of Malaya, Kuala \\ Lumpur,Malaysia \\ Abdul Razak Ibrahim \\ Department of Marketing and Information Systems, Faculty of Business and Accountancy, University of Malaya, \\ KualaLumpur, Malaysia \\ Ainin Sulaiman \\ Department of Marketing and Information Systems, Faculty of Business and Accountancy, University of Malaya, \\ KualaLumpur, Malaysia \\ Sharifah Latifah Syed A. Kadir \\ Faculty of Business and Accountancy, University of Malaya, Kuala Lumpur, Malaysia
}

\begin{abstract}
This study purposively is to conduct an empirical analysis of the structural relations among critical factors of quality management practices (QMPs), world-class company practice (WCC), operational excellence practice (OE), and company performance (company non-financial performance or CNFP and company financial performance or CFP) in the oil and gas companies operating in Indonesia. The current study additionally examines the relationships between QMPs and CFP through WCC, OE, and CNFP (as partial mediators) simultaneously. The study uses data from a survey of 140 strategic business units (SBUs) within 49 oil and gas contractor companies in Indonesia. The findings suggest that all six QMPs have positive and significant indirect relationships on CFP through WCC and CNFP. Only four of six QMPs have positive and significant indirect relationships on CFP through OE and CNFP. Hence, WCC, OE, and CNFP play as partial mediators between QMPs and CFP. CNFP has a significant influence on CFP. A major implication of this study is that oil and gas managers need to recognize the structural relations model fit by developing all of the research constructs simultaneously associated with a comprehensive TQM practice. Furthermore, the findings will assist oil and gas companies by improving CNFP, which is very critical to TQM, thereby contributing to a better achievement of CFP. The current study uses the Deming's principles, Hayes and Wheelwright dimensions of world-class company practice, Chevron Texaco's operational excellence practice, and the dimensions of company financial and nonfinancial performances. The paper also provides an insight into the sustainability of TQM implementation model and their effect on company financial performance in oil and gas companies in Indonesia.
\end{abstract}

Corresponding authors. E-mail: wakhidsciptono@mmugm.ac.id

ISSN: $1141-1128$

http://www.gamaijb.mmugm.ac.id/ 


\begin{abstract}
Abstrak: Studi ini bertujuan untuk melakukan analisis empiris hubungan struktural antara faktor-faktor kritis dari praktik-praktik kualitas manajemen (QMPs), praktik perusahaan kelas dunia (WCC), praktik keunggulan operasional (OE), dan kinerja perusahaan (kinerja-non-keuangan perusahaan atau CNFP dan kinerja-keuangan perusahaan atau CFP) di perusahaan minyak dan gas yang beroperasi di Indonesia. Tambahan studi ini meneliti hubungan antara QMPs dan CFP melalui WCC, OE, dan CNFP (sebagai mediator parsial) secara bersamaan. Studi ini menggunakan data dari survei terhadap 140 unit bisnis strategis (SBU) dengan 49 kontraktor perusahaan minyak dan gas di Indonesia. Dari temuan menunjukkan bahwa enam QMPs memiliki hubungan positif yang tidak langsung dan signifikan terhadap CFP melalui WCC dan CNFP. Hanya empat dari enam QMPs memiliki hubungan positif yang tidak langsung dan signifikan terhadap CFP melalui OE dan CNFP. Oleh karena itu, WCC, OE, dan CNFP berperan sebagai mediator parsial antara QMPs dan CFP. CNFP yang mempunyai pengaruh signifikan pada CFP. Implikasi utama dari penelitian ini adalah, bahwa manajer perusahaan minyak dan gas perlu mengenali betul hubungan model struktural, dengan mengembangkan konstruk penelitian secara bersamaan yang dikaitkan dengan praktik TQM yang komprehensif. Selanjutnya, dari temuan, akan membantu perusahaan minyak dan gas dalam meningkatkan CNFP, yang sangat penting untuk TQM, sehingga berkontribusi untuk pencapaian kinerja yang lebih baik dari CFP. Studi ini menggunakan prinsip-prinsip Deming, Hayes dan Wheelwright berdimensi praktik perusahaan kelas dunia, praktik keunggulan operasional Chevron Texaco, dan dimensi kinerja-keuangan dan non-keuangan perusahaan. Paper ini juga memberikan wawasan tentang keberlanjutan model implementasi TQM dan efeknya pada kinerja keuangan perusahaan di perusahaan minyak dan gas di Indonesia.
\end{abstract}

Keywords: company performance; Indonesia; operational excellence; total quality management, world-class company 


\section{Introduction}

A successful TQM implementation should consider other contemporary management practices such as learning organization through operational excellence practice, world-class organization (i.e. world-class company practice), and performance management (i.e. company performance) as an integrated network (connection) of management practices (Luthans et al. 1995). TQM researchers- to develop a comprehensive TQM implementation modelhas sought out the contextual factors affecting TQM effectiveness (Montes et al. 2003). Gilbert (1992) and Raffio (1992) cited in Montes et al. (2003) argue that, when a TQM program is properly implemented, the company productivity and/or profitability will improve then.

Thus, it can be concluded that this improvement is a result of the TQM implementation program. Nonetheless, the improvement noticed essentially could have originated as a result of other events concurrent in time along with an intervention. This means that a relationship between the improvement process and the organizational results could have been obscured by some exogenous shocks-contextual factors of TQM implementation such as environmental or market factors (Montes et al. 2003). Hence, a concern must be deeply given to the conceptual and contextual factors and attempts are needed to realize that TQM implementation should not be operated separately from other change initiative programs (contextual factors) - it actually could be integrated instead. This study in turn is also designed to investigate the rationale of linkage among ten research constructs (including two contextual factors) - six critical factors of quality management practices, world- class company practice, operational excellence practice, company non-financial performance, and company financial performance.

In fact, TQM is described as a total system approach (Sitkin et al. 1994) in which one of its major principles is the appreciation of systems (Leonard and McAdam 2003). Therefore, a collaboration of TQM with other theories and practices as a total system will be able to assist in developing TQM dynamics models (Vancouver 1996; Leonard and McAdam 2003). Here, the study by the researchers is designed to develop a comprehensive model of TQM implementation by empirically examining and focusing on the structural relations of critical factors among quality management practices, contextual factors related to TQM implementation (world-class company practice, operational excellence practice), and company performance (financial and non-financial) based on management perception in the oil and gas industries in Indonesia. By testing the model the researchers suggest that structural relations among six critical factors of quality management practices(or QMP), world-class company practice (WCC), operational excellence practice (OE), and company non-financial performance (CNFP) may lead to superior company financial performance (CFP) using structural equation modeling (SEM).

SEM is a collection of statistical techniques which in this study is used to allow a set of complex relations among one endogenous variable (CFP), six exogenous variables (QMP1-6), and three mediating variables (WCC, OE, CNFP)- to be examined. For the complexity and multidimensionality in the phenomena of interest, SEM is considered to be the only tool of analysis that allows complete and simultaneous tests of all the relations (Ullman 2006). 
The primary purpose of the current study is to offer a new empirical evidence on the form and strength of the structural relations among critical factors of quality management practices (exogeneous variables), world-class company practice, operational excellence practice, company non-financial performance (mediating variables) and company financial performance (an endogeneous variable) in oil and gas business units that have adopted TQM. A theoretical support for the constructs used in this investigation primarily comes from the total quality management and sustainability strategic disciplines. In summary, the objectives of the current study are as follows:

(1) to examine the relationships between critical factors of quality management practices and world-class company practice;

(2) to examine the relationships between critical factors of quality management practices and operational excellence practice;

(3) to reveal world-class company practice and company non-financial performance partially mediating the relationhips between critical factors of quality management practices and company financial performance;

(4) to reveal operational excellence practice and company non-financial performance partially mediating the relationships between critical factors of quality management practices and company financial performance; and

(5) to find out the significant influence of company non-financial performance on the company financial performance.

\section{Sustainability of TQM Implementation Program}

The implementation of sustainability of TQM needs to change from a predominantly narrow and mechanistic approach, with quality basically rested on hard elements related to production or systematic measurement of standard operating procedure (SOP) - to a softer or more social (organic and cultural) procedure (McAdam 2000, cited in Sa and Abrunhosa 2007; Bou and Beltran 2005). The mechanistic approach of TQM, by emphasizing stability, conformity, and discipline, as a matter of fact does not introduce enough looseness into the system for people to explore new possibilities and collaborate with others. In contrast, the organic approach of TQM, by stressing leadership, involvement, empowerment, partnerships, and comparison with the best in class (benchmarking), has encouraged people to scan the environment for new trends, information communication technology (ICT), knowledge management, and changes in mindsets (continuous innovation) (McAdam 2004, in Sa and Abrunhosa 2007).

Sustainability of TQM implementation is a comprehensive management philosophy, embracing all the aspects of organization and involving its entire workforce, including customers and suppliers (Dale 1994). Implementing sustainability of TQM program is expected to enhance organizational performance (sustainable competitive advantage). The effectiveness of this implementation however should be realized by accessing and utilizing the concerted knowledge and experience of managers and employees at all levels (Kossoff 1993, in Melan 1998). 
Since TQM is an organization-wide function, organization theory should be used to describe, explain, and improve it. Organization-theory research could significantly contribute to the practice of TQM and, in turn, improve quality performance and company performance (Benson et al. 1991). One of the organization theories is the "mechanistic-organic" approach. An effective sustain-ability TQM implementation program in an organization uses a combination of both mechanistic and organic approaches. Organizations are viewed as the instruments designed to efficiently achieve several specified goals. As the contingency theory posits, a mechanistic approach will be more useful in a more stable business environment, whereas an organic approach will be more effective in a turbulent, dynamic and complex business environment. This contingency theory is supported by Paul Lawrence and Jay Lorsch's work (Lawrence and Lorsch 1967).

Figure 1. The Proposed Structural Relations Model

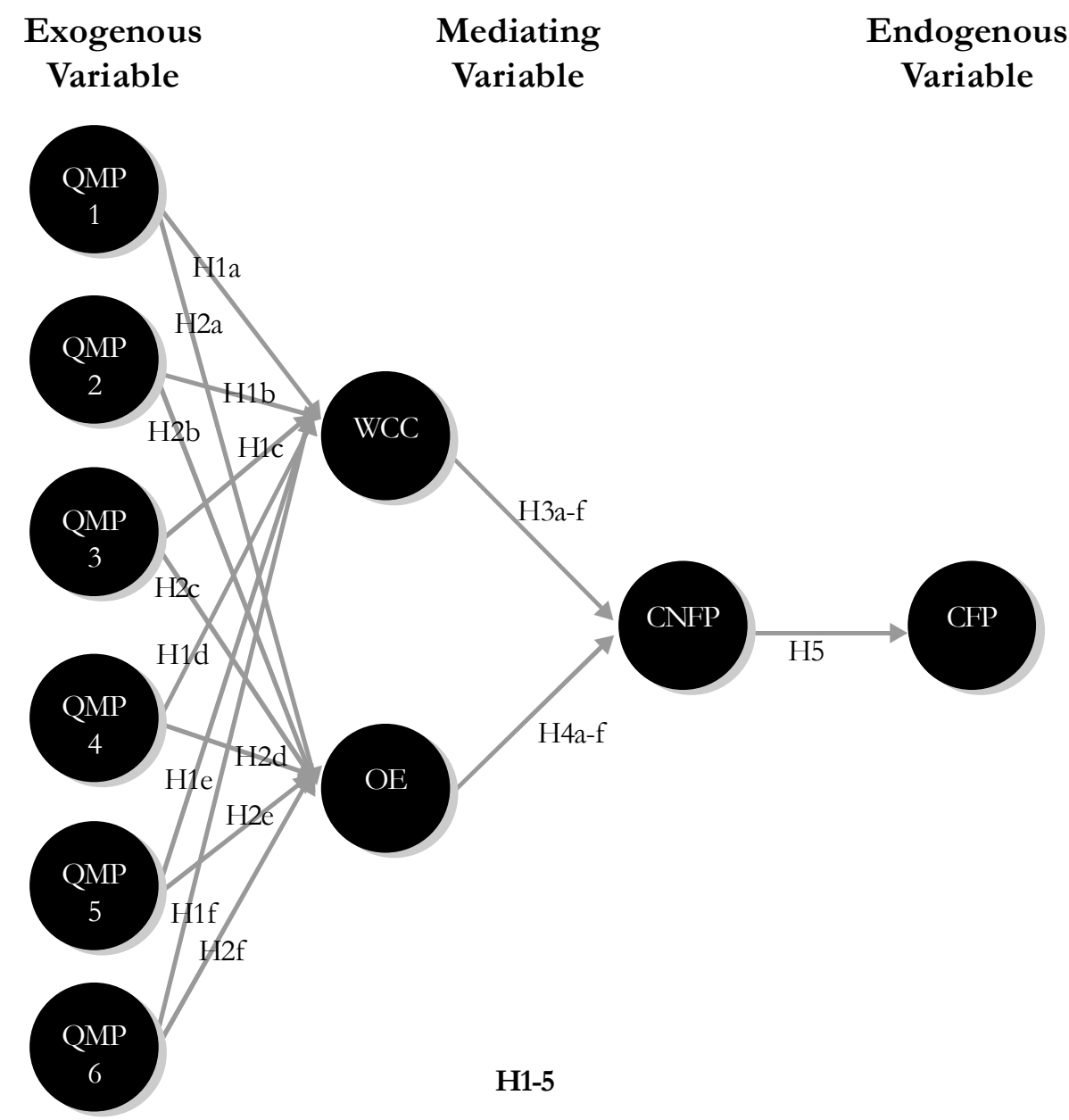

Note:

- QMPs: Critical Factors of Quality Management Practices

- OE: Operational Excellence Practice

- WCC: World-class Company Practice

- CNFP: Company Non Financial Performance

- CFP: Company Financial Performance 


\section{Research Framework and Hypothesis}

The hypothesized overall structural relations model is portrayed in Figure 1. It is important to recognize that Figure 1 represents a series of structural relations between six exogeneous variables (QMPs) and an endogeneous variable (CFP) through three mediating variables (WCC, OE, and $\mathrm{CNFP}$ ).

\section{Relationships between QMPs and $W C C$, and $Q M P S$ and $O E$}

The critical factors of quality management practices (QMPs) have been defined as an approach to management made up of a "set of mutually reinforcing principles, each of which is supported by a set of practices and techniques" (Dean and Bowen 1994), which has achieved a discriminant validity with respect to other strategies for improving the organization's performance (Hackman and Wageman 1995, in Molina et al. 2006). According to Hoskinsson et al. (1999) in Molina et al. (2006), studies of strategic management explain an improvement in the firm's performance along two lines: (a) the classic studies of the industrial economy, which believe that improvement in a performance comes from a better position of the firm, that is, from finding an environment that favors the firm; and (b) the vision of resources and capacities, which believes that the firm should focus on improving its contextual factors (i.e. knowledge and abilities about critical factors of quality management practices, world-class company practice, and operational excellence practice) to improve its performance (company non-financial and company financial performances). Accordingly, we argue that critical factors of quality man- agement practices (QMPs) lead to worldclass company practice (WCC) and operational excellence practice (OE). We then hypothesize that:

\section{H1a-f : All critical factors of quality management practices will significantly influence world- class company practice. \\ H2a-f : All critical factors of quality management practices will significantly influence opera- tional excellence practice.}

\section{Mediation}

Adapting the studies of Demirbag et al. (2006) and Molina (2006), the mediating role of world-class performance in operations (world-class company practice, operational excellence practice, and company non-financial performance) among critical factors of quality management practices and company financial performance will be found to be only partial (partial mediation). In fact, the mediation role could be fully given (complete) as well. In the present study, one of the objectives is to explore the mediating role (partial mediation) of world-class company practice, operational excellence practice, and company non-financial performance between critical factors of quality management practices and company financial performance. We- for this, propose the following hypotheses:

H3: World-class company practice and company non-financial performance partially mediate the impact of critical factors of quality management practices on company financial performance.

H4: Operational excellence practice and company non-financial performance partially mediate the impact of critical factors of quality management practices on company financial performance. 


\section{Relationships between CNFP and $C F P$}

According to Ittner and Larcker (1998), non-financial indicators of improvements in areas such as quality, customer or employee satisfaction, and innovation may be better predictors of future financial performance than historical accounting measures, and should supplement financial measures in internal accounting systems (e.g. Deloitte Touche Tohmatsu International 1994, and Kaplan and Norton 1996). This same discussion has produced calls for disclosure of nonfinancial information on the drivers of firm value (e.g. Wallman 1995; Edvinsson and Malone 1997; and Stewart 1997). A report by the American Institute of Certified Public Accountants (1994), for instance, concludes that companies should disclose leading, non-financial measures on key business processes such as product quality, cycle time, innovation, and employee satisfaction (Ittner and Larcker 1998). Based on these reasons, the researcher finds that company non-financial measures are leading indicators of company financial performance (Hendricks and Singhal, 2003; Dehning et al. 2004; Skrinjar et al. 2008). On the basis of the above-mentioned relationship between company non-financial performance and company financial performance, we develop the following hypothesis:

H5: Company non-financial performance will positively influence company financial performance.

\section{Research Method}

A survey questionnaire was mailed and e-mailed to 2,800 oil and gas business unit managers of a random sample of 49 oil and gas companies in Indonesia chosen from the Directorate General of Oil and Gas of the
Republic of Indonesia. A total of 1,332 individual usable questionnaires were received for a response rate of 50.19 percent. The survey reveals that the respondents (business unit managers) were 354 top level managers, 447 middle level managers, and 531 low level managers. Non-response bias was conducted between early and late responders. In addition, the results of the structural relations model using the total 1,332 usable responses obtained from the initial mail- and email-out were compared. Here no significant differences were found in any of the comparisons indicating the absence of non-response bias.

\section{Variable Measurement}

\section{Exogeneous Variables (Six QMPs)}

Six QMPs are applied by using a set of 50 items of quality management method (qmm150). These fifty quality management methods (QMMs) can be extracted (classified) by six meaningful dimensions of six QMPs using the exploratory factor analysis-quality improvement program (QMP1), supervisory leadership (QMP2), supplier involvement (QMP3), top management commitment (QMP4), training to improve products/services (QMP5), and cross-functional team relationships among strategic business units (QMP6). Fifty quality management methods are developed to measure Deming's 14 points based on a thorough literature review focused on the writings of Ahire et al. (1996a), Saraph et al. (1989), Tamimi (1995 and 1998).

\section{Mediating Variables (World-Class Performance in Operations: $W C C, O E$, and $\mathbf{C N F P}$ )}

This study employed world-class performance in operations for the mediating construct. Wright and Geroy (2001) argue that world-class performance in operations is de- 
rived from a complex set of interacting practices between WCC and OE-the contextual factors of oil and gas companies. In developing world-class performance in operations, the managers consider that most of SBUs in the Indonesia's oil and gas industry are cost centers for relying much on the non-financial performance.

In addition, if a non-financial performance is excellent, it might be sufficient to gain a better financial performance and lead business to success. According to Ittner and Larcker (1998), non-financial measures are the leading indicators of financial performance. Moreover, non-financial performance becomes the key business processes such as by offering quality of product and service, delivery of product and service, variety of products and services, customer satisfaction, employee satisfaction, and community involvement. "Generally, non-financial performance has no any intrinsic value for company directors. Rather, this can be used as a leading indicator of financial performance and, especially, future financial performance that is not contained in contemporary accounting measures" (Prieto and Revilla 2006: 171) — the linkage between CNFP and CFP.

Oil and gas managers that wish to compete in the world-class competition must produce evidence of leadership and commitment, initiate verifiable cross-functional communications, address the happiness and wellbeing of the workforces through better nonfinancial performances, and, above all, work toward their sustainable competitive advantage achievement - from TQM to corporate sustainability based on a stakeholder management" (Zink 2007: 394). According to Prajogo and Sohal (2004b), sustainability of TQM implementation needs to be implemented and aligned with the company's business strategy.
Also, organizations need to simultaneously pursue several multiple aspects of performance-including quality and innovation.

World-Class Company Practice (WCC) is applied by using sixty-seven (67) Hayes and Wheelwright dimensions. Hayes and Wheelwright (1984) developed their concept of world-class manufacturing based on six principles. Specifically, a confirmatory factor analysis is employed to determine whether Hayes and Wheelwright's 67 dimensions possess a positive and significant effect on their six principles. The study develops a secondorder confirmatory factor analysis to test whether a set of Hayes and Wheelwright principles lands on an overall construct that may be termed as a WCC. The measure is developed by Flynn et al. (1999). The term WCC is applied since these firms are associated with outstanding performance in the global oil and gas industry.

\section{Operational Excellence Practice} $(\mathrm{OE})$ is applied by using five dimensions of operational excellence practices in the oil and gas industry: safety, environment, health, reliability, and efficiency. The measures are adapted from Parker (1999) and Chevron Texaco's program (2003). It is the policy of Chevron-Texaco Corporation to protect the safety and health of people and the environment- and to reliably and efficiently conduct the operations. The systematic management of safety, environment, health, reliability, and efficiency to achieve world-class performance is defined as an OE.

Company Non-Financial Performance (CNFP) is applied as an ability of a company to increase its financial performance by increasing its non-financial performance. The measures are adapted from Carpenter and Sanders, 2007; Cook and Verma 2002; and Demirbag et al. 2006. CNFP consists of six 
items; namely product/service quality enhancement, delivery performance, delivery of product/service, customer satisfaction, employee satisfaction, and community development impacts that can be better indicators of future financial performance). By implementing non-financial measures, oil and gas managers can communicate its vision and mission and provide incentives for managers in achieving profitability, competitive strength, and longer-term strategic goals (Knowledge@wharton 2000).

\section{Endogenous Variable (Company Financial Performance)}

Company financial performance (CFP) or monetary-gain performance consists of three items: profit, market-share enhancement, and cost reduction. The measures are adapted from Carpenter and Sanders 2007; Cook and Verma 2002; and Demirbag et al. 2006. Financial measures generally focus on a short-term performance against financial/ accounting data. Richardson et al. (2002) argued that although improvement in financial performance is critical to many organizations, firms may also regard paying attention to the significance of non-financial performance factors. Banker et al. (2000) reported that few studies have addressed a correlation between non-financial and financial performance (Dunk 2005). In response, this study develops a linkage between non-financial and financial performance as an integral part of the structural relations between QMP and CFP.

As the financial and non-financial data in this study were collected from oil and gas managers on the basis of their subjective evaluations (perceptions), objective financial and non-financial performance indicators are not employed in the analysis. Overall financial and non-financial performances were measured subjectively. In organizational re- search subjective performance measures are widely accepted (Lawrence and Lorsch 1967; Dess 1987; Powell 1992 in Powell 1995). This research included 47 privately-held oil and gas firms that would not have provided confidential financial information as a matter of policy.

\section{Results}

Table 1 and Figure 2 show the revised (final) structural model. After eliminating the paths, QMP3 to OE, QMP6 to OE were iteratively used to determine whether the structural model fit the data well. The criteria for assessing overall fit support a well-fitting model $\left(\mathrm{X}^{2} / \mathrm{df}<2\right.$; GFI, AGFI, CFI > 0.95 ; RMR and RMSEA $<0.05$; and $\mathrm{p}$-value $>$ 0.05). Sub-hypotheses H2c and H2f were not supported-QMP ${ }_{3}$ and $\mathrm{QMP}_{6}$ did not have a strong positive impact on OE. With some modifications, the results of the final model support sub-hypotheses H2a, b, d, e (see Figure 2).

The revised (final) model surpasses the hypothesized model on all fit criteria, which confirms that the modifications were meaningful. There were no examples of parameters exhibiting the unreasonable estimates (e.g. no correlations greater than 1.0 and negative correlations). This result also provides several important insights into all the lowest and smallest ECVI (Expected Cross-Validation Index) values from the initial model (ECVI $=0.080$ ), and final causal model (ECVI $=$ 0.079). According to Byrne (2001) the structural model having the smallest ECVI values exhibits the greatest potential for replication. In assessing the hypotheses for the structural model (Final Causal Model), the researchers compared ECVI value of 0.079 with that of both the saturated model $(\mathrm{ECVI}=0.075)$ and the independence model (ECVI $=3.065)$. 
Table 1. SEM Results (Revised Model/Final Causal Model)

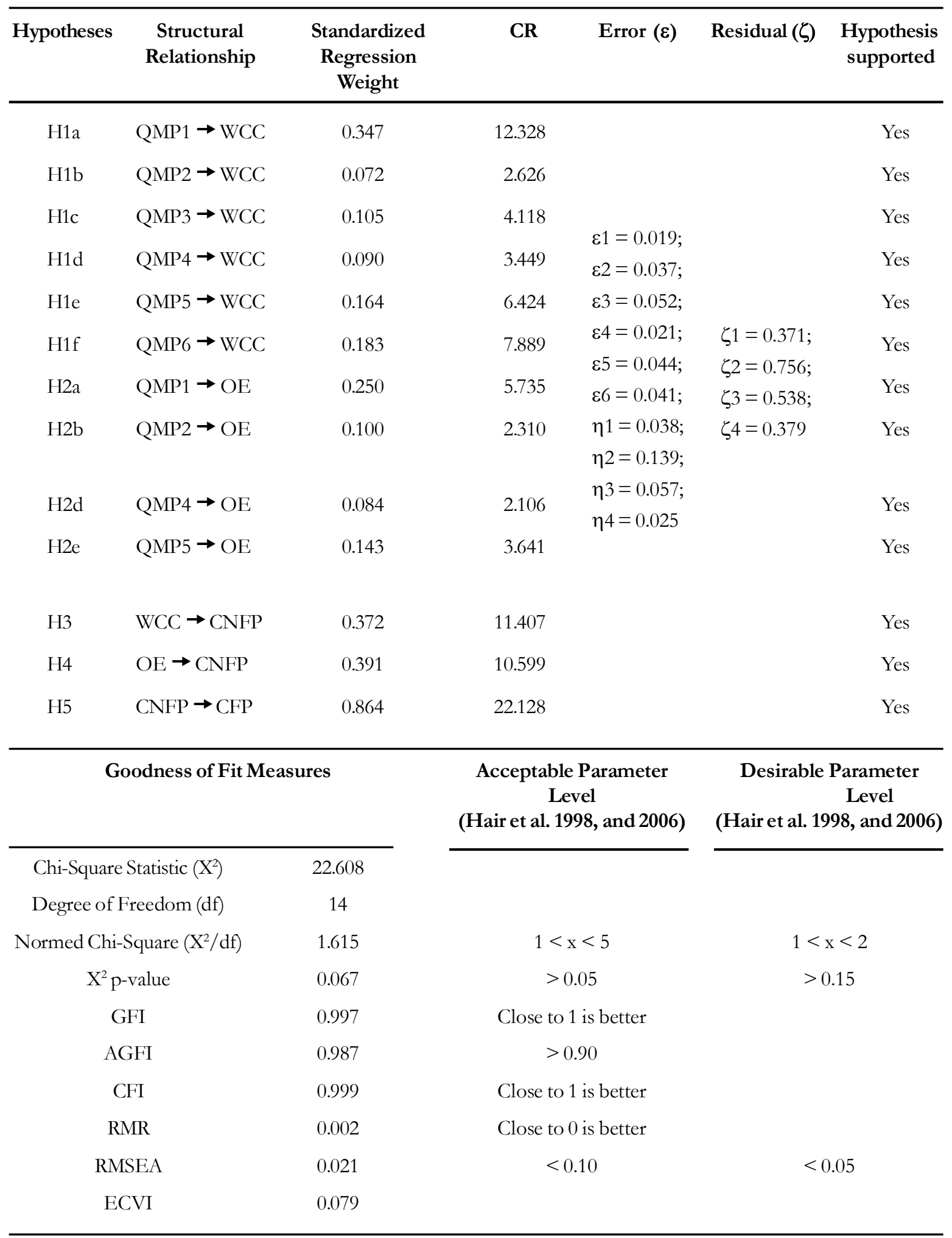


Figure 2. The Revised (Final) Model of the Structural Relations of Sustainability of TQM Implementation

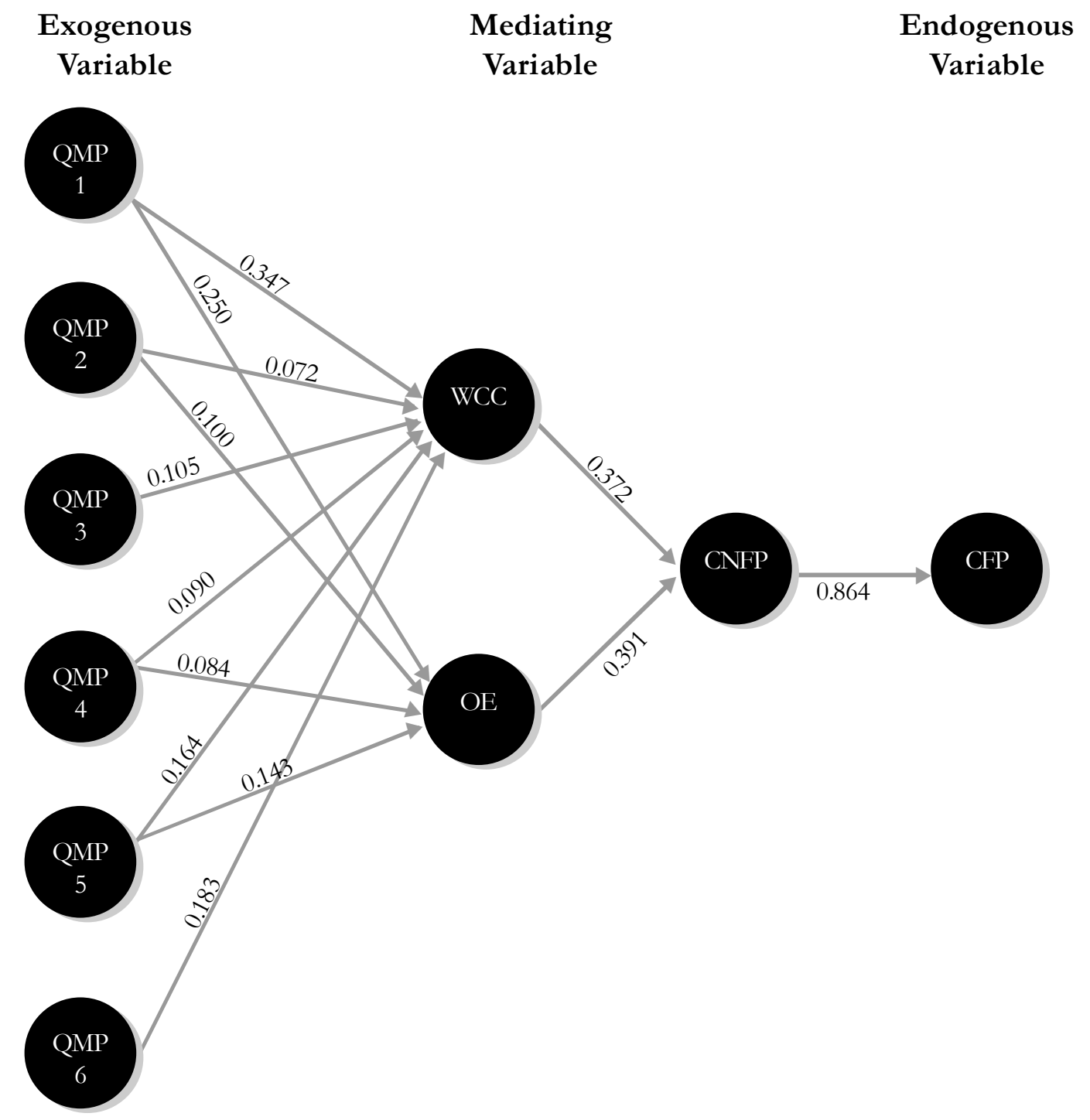

Note:

- $\mathrm{QMP}_{1-6}$ : Critical Factors of Quality Management Practices

- OE: Operational Excellence Practice

- WCC: World-class Company Practice

- CNFP: Company Non Financial Performance

- CFP: Company Financial Performance 
Given the lower ECVI value for the hypothesized model, compared with both the independence and saturated models, the researchers conclude that it represents the best fit to the data.

\section{Decomposition of Effects in Path Analysis}

To test hypotheses 3 and 4, the researchers use the decomposition of effects in path analysis to examine the total effect of QMP1-6 on CFP through two mediating variables (WCC and CNFP; OE and CNFP). Table 2 presents the estimated coefficients of regression equations used to interpret the structural relations in TQM implementation in Figure 2.

Table 3 illustrates the result of the decomposition of effects in path QMP1-6 $g$ $\mathrm{WCC} \rightarrow \mathrm{CNFP} \rightarrow \mathrm{CFP}(\mathrm{H} 4 \mathrm{a}-\mathrm{f})$ and in path QMP1-6 $\rightarrow$ OE $\rightarrow$ CNFP $\rightarrow$ CFP $(\mathrm{H} 5 \mathrm{a}-\mathrm{f})$. It is important to interpret patterns of direct and indirect causation in structural relations model (Figure 1). These results imply that H4a-f and H5a, b, d, and e were accepted. Hence, WCC and CNFP partially mediate the impact of six QMPs (QMP1-6) on CFP. OE and CNFP similarly partially mediate the impact of four QMPs (QMP1, 2, 4, 5) on CFP.

To learn how a particular mediating variable exercises its effect, the researchers decompose the indirect effects into their constituent parts. To determine hypotheses 3 , for example, the result shows that QMP1 has the total effect of 0.227 on CNFP, of which 0.129 is transmitted via WCC; and QMP1 has an indirect effect of 0.196 on CFP through CNFP. There is no direct effect of QMP1 to CNFP and CFP. The same ways that QMP2,3,4,5,6 have total effects of 0.076, $0.039,0.066,0.177$, and 0.068 on CNFP, of which $0.037,0.039,0.033,0.061$, and 0.068 are transmitted via WCC; and QMP2,3,4,5,6

Table 2. Coefficients of Variables Based on the Final Model of the Structural Relations of TQM Implementation

\begin{tabular}{lcccc}
\hline & \multicolumn{4}{c}{ Equation and Dependent Variable } \\
\cline { 2 - 5 } $\begin{array}{c}\text { Predetermined } \\
\text { Variable }\end{array}$ & $\mathbf{( 1 )}$ & $\mathbf{( 2 )}$ & $\mathbf{( 3 )}$ & $\mathbf{( 4 )}$ \\
\hline $\mathrm{QMP}_{1}$ & 0.347 & 0.250 & - & CF \\
$\mathrm{QMP}_{2}$ & 0.072 & 0.100 & - & - \\
$\mathrm{QMP}_{3}$ & 0.105 & - & - & - \\
$\mathrm{QMP}_{4}$ & 0.090 & 0.084 & - & - \\
$\mathrm{QMP}_{5}$ & 0.164 & 0.143 & - & - \\
$\mathrm{QMP}_{6}$ & 0.183 & - & - & - \\
$\mathrm{WCC}$ & - & - & 0.372 & - \\
$\mathrm{OE}$ & - & - & 0.391 & 0.864 \\
CNFP & - & - & - & - \\
\hline
\end{tabular}


have indirect effects of $0.066,0.034,0.057$, $0.101,0.059$ on CFP through CNFP. There are no direct effects of QMP2,3,4,5,6 to CNFP and to CFP. These results imply that H3a,b,c,d,e,f were accepted-WCC and CNFP partially mediate the impact of QMP1,2,3,4,5,6 on CFP.

To determine hypothesis 4 , the results show that QMP1,2,4,5 have total effects of $0.227,0.076,0.066$, and 0.177 on CNFP, of which $0.098,0.039,0.033$, and 0.056 are transmitted via OE; and QMP1,2,4,5 have indirect effects of $0.066,0.034,0.057,0.101$, 0.059 on CFP through CNFP. There are no direct effects of QMP1,2,4,5 to CNFP and to CFP. The results imply that H4a,b,d,e were supported-OE and CNFP partially mediate the impact of QMP1,2,4,5 on CFP. Hypotheses $\mathrm{H} 3 \mathrm{c}$,f were not supported-OE and CNFP do not mediate the impact of QMP3,6 on CFP.

Table 3. Interpretations of Decomposition of Effects in Path Analysis

\begin{tabular}{|c|c|c|c|c|c|c|}
\hline \multirow[b]{2}{*}{$\begin{array}{c}\text { Dependent } \\
\text { Variable }\end{array}$} & \multirow[b]{2}{*}{$\begin{array}{c}\text { Predetermined } \\
\text { Variable }\end{array}$} & \multirow[b]{2}{*}{$\begin{array}{l}\text { Total } \\
\text { Effect }\end{array}$} & \multicolumn{3}{|c|}{ Indirect Effects via } & \multirow[b]{2}{*}{$\begin{array}{l}\text { Direct } \\
\text { Effect }\end{array}$} \\
\hline & & & WCC & $\mathrm{OE}$ & CNFP & \\
\hline \multirow[t]{6}{*}{ WCC } & $\mathrm{QMP}_{1}$ & 0.347 & - & - & - & 0.347 \\
\hline & $\mathrm{QMP}_{2}$ & 0.072 & - & - & - & 0.072 \\
\hline & $\mathrm{QMP}_{3}$ & 0.105 & - & - & - & 0.105 \\
\hline & $\mathrm{QMP}_{4}$ & 0.090 & - & - & - & 0.090 \\
\hline & $\mathrm{QMP}_{5}$ & 0.164 & - & - & - & 0.164 \\
\hline & $\mathrm{QMP}_{6}$ & 0.183 & - & - & - & 0.183 \\
\hline \multirow[t]{6}{*}{$\mathrm{OE}$} & $\mathrm{QMP}_{1}$ & 0.250 & - & - & - & 0.250 \\
\hline & $\mathrm{QMP}_{-}$ & 0.100 & - & - & - & 0.100 \\
\hline & $\mathrm{QMP}_{3}$ & - & - & - & - & - \\
\hline & $\mathrm{QMP}_{4}$ & - & - & - & - & - \\
\hline & $\mathrm{QMP}_{5}$ & 0.143 & - & - & - & 0.143 \\
\hline & $\mathrm{QMP}_{6}$ & 0.183 & - & - & - & 0.183 \\
\hline \multirow[t]{8}{*}{ CNFP } & $\mathrm{QMP}_{1}$ & 0.227 & 0.129 & 0.098 & - & 0.000 \\
\hline & $\mathrm{QMP}_{-}$ & 0.076 & 0.037 & 0.039 & - & 0.000 \\
\hline & $\mathrm{QMP}_{3}$ & 0.039 & 0.039 & - & - & 0.000 \\
\hline & $\mathrm{QMP}_{4}$ & 0.066 & 0.033 & 0.033 & - & 0.000 \\
\hline & $\mathrm{QMP}_{5}$ & 0.177 & 0.061 & 0.056 & - & 0.000 \\
\hline & $\mathrm{QMP}_{6}$ & 0.068 & 0.068 & - & - & 0.000 \\
\hline & WCC & 0.372 & - & - & - & 0.372 \\
\hline & $\mathrm{OE}$ & 0.391 & - & - & - & 0.391 \\
\hline
\end{tabular}




\begin{tabular}{ccccccc}
\hline & & & \multicolumn{2}{c}{ Indirect Effects via } & \\
\cline { 5 - 6 } $\begin{array}{c}\text { Dependent } \\
\text { Variable }\end{array}$ & $\begin{array}{c}\text { Predetermined } \\
\text { Variable }\end{array}$ & $\begin{array}{c}\text { Total } \\
\text { Effect }\end{array}$ & WCC & OE & CNFP & $\begin{array}{c}\text { Direct } \\
\text { Effect }\end{array}$ \\
\hline \multirow{2}{*}{ CFP } & QMP $_{1}$ & 0.196 & - & - & 0.196 & 0.000 \\
& $\mathrm{QMP}_{2}$ & 0.066 & - & - & 0.066 & 0.000 \\
& $\mathrm{QMP}_{3}$ & 0.034 & - & - & 0.034 & 0.000 \\
& $\mathrm{QMP}_{4}$ & 0.057 & - & - & 0.057 & 0.000 \\
& $\mathrm{QMP}_{5}$ & 0.101 & - & - & 0.101 & 0.000 \\
& $\mathrm{QMP}_{6}$ & 0.059 & - & - & 0.059 & 0.000 \\
$\mathrm{CNFP}$ & 0.864 & - & - & - & 0.864 \\
\hline
\end{tabular}

\section{Conclusion}

The summary of the quantitative research findings of the study is about the testing results from the research hypotheses:

Hypotheses 1a-f: determining six critical factors of quality management practices have positive impacts on world-class company practice.

Hypotheses 2a-f: determining four critical factors of quality management practices have positive impacts on operational excellence practice.

Hypothesis 3: world-class company practice and company non-financial performance partially mediate the impact of six critical factors of quality management practices on company financial performance.

Hypothesis 4: operational excellence practice and company non-financial performance partially mediate the im- pact of four critical factors of quality management practices on company financial performance.

Hypothesis 5: company non-financial performance has a strong positive impact on company financial performance.

\section{Discussion}

Overall, the results of SEM indicate that six QMPs (quality improvement, supervisory leadership, supplier involvement, top management commitment, training to improve products/services, and cross functional relationships among strategic business units or SBUs) significantly and positively are related to WCC. Four QMPs (quality improvement, supervisory leadership, top management commitment, and training to improve products/services) are significantly associated with OE. Furthermore, WCC and OE significantly affect CNFP, which in turn has a strong significant effect on CFP. 
In this study, it is found that six QMPs $\left(\mathrm{QMP}_{1-6}\right)$ had significant positive impacts on WCC simultaneously suggesting that there are synergies among six QMPs $\left(\mathrm{QMP}_{1-6}\right)$ possible to oil and gas companies, which employ WCC. This is in line with the work of Flynn et al. (1999), who determined that WCC- significantly- is related to QMP (cost, quality performance, product flexibility, and volume flexibility). According to Flynn et al. (1999), QMPs allow competition on the basis of dependability, which WCC- separately- was not able to achieve.

The relationship among four of six QMPs $\left(\mathrm{QMP}_{1,2,4,5}\right)$ is presented in Figure 2. This study observes that $\mathrm{OE}$ is always becoming essential in developing oil and gas business based on the QMPs. Findings indicated that quality improvement program, training to improve products/services, supervisory leadership, and top management commitment, are positively associated with operational excellence in the oil and gas industry. It asserted that the adoption of QMPs into OE could help to alter an oil gas company to understand the controls from a pointin-time crude oil/natural gas exploration project implementation mindset to a sustainable approach embedded into day-to-day operational processes. Hence, the need to adopt QMPs is vital to promote OE. To make OE successful, the integration of quality improvement program, training to improve products/ services, supervisory leadership, and top management commitment must be in harmony.

It is observed that there is a strong relationship between a set of WCC (six dimensions of Hayes and Wheelwright's practices: workforce skills and capabilities, management technical competence, competing through quality, workforce participation, rebuilding manufacturing engineering, and incremental improvement approaches) and a set of CNFP (quality of products/service offerings, delivery of products/service offerings, and variety of products/service offerings, customer satisfaction, employee satisfaction, and community involvement). This is consistent with the findings of Flyn et al. (1999) stating that WCC was related to cost, quality, and flexibility (CNFP).

The study also observed that there is a strong relationship between a set of $\mathrm{OE}$ (safety, environment, health, reliability, and efficiency) and a set of CNFP (quality of products/service offerings, delivery of products/service offerings, and variety of products/service offerings, customer satisfaction, employee satisfaction, and community involvement). OE is necessary for oil and gas industry survival, which will be a source of sustainable competitive advantage (Thompson et al. 2010).

The study determined that CNFP has a strong positive impact on CFP. Performance is a multifaceted concept and this study tried to capture performance dimensions from both financial (financial performance, market performance, and operating costs) and non-financial (quality of products/service offerings, delivery of products/service offerings, and variety of products/service offerings, customer satisfaction, employee satisfaction, and community involvement). Rather than individual practices, these findings were interpreted only by sets of CNFP and CF- due to the use of the first-order constructs as indicators of the second-order construct.

\section{Limitations and Suggestions for Future Research}

Despite the fact that this study develops a sustainability of TQM implementation model in the fields of TQM and sustainability 
strategic, it should also be acknowledged that the study is subject to some methodological limitations.

First, the data in this study were collected from managers at top, middle, and low level on the basis of their subjective evaluations, and objective performance indicators should be employed in an analysis.

Second, the research reported here is of a purely cross-sectional snapshot. The researchers were unable to test and account for the lags between the existence of practices and performance changes, nor to trace the progress of particular oil and gas companies in this study, which is a limitation of all such studies. The researchers also encourage thinking about whether the model of the study variously changes at certain times, either because the constructs are theoretically important in other times or because the theoretical effect is unstable for some reasons. Future research should be conducted longitudinally to observe the progress of improvement efforts.

Third, there is a need for further research to develop further TQM dynamics model both in theory and in practice. To do so, the neural network model and triangulation method could be utilized in future studies to gain additional insights in exploring the structural relationships among quality management practices, contextual factors of an organization, and company performance.

Finally, in this study, SEM was employed to examine more complicated structural relations among one or more dependent (endogenous) variables and two or more predicting (mediating or independent/exogenous) variables simultaneously (i.e. sustainability of TQM implementation model for oil and gas industry in Indonesia) that cannot be handled by other techniques such as path analysis. Basically, SEM expects a large sample size to achieve a more accurate solution.

In order to conduct this type of study, researchers need to keep in mind four crucial elements: first, researchers must carefully design a research model to minimize the problem in reliability and validity. This type of research needs to be precise enough to demonstrate that a potential cause and effect could have covariance. In addition, all research constructs that are confounding variables must be ruled out.

Second, a cross-cultural comparative study can be suggested as another promising research topic based on the same measurement scales. Since the measurement scales for this study are largely focused on the managerial elements related to sustainability of TQM implementation model and organizational improvement, the assessment and analysis of management activities in a different cultural setting may prove quite interesting. To accomplish this cross-cultural comparative study, researchers must carefully select the sample country so that sustainability of TQM implementation model is already in place there. At a minimum, very similar principles of TQM should be employed organizationwide. The promising benefit of this type of study is that researchers can identify how cultural differences affect the same management philosophy.

Third, it is reasonable to assume that firms reserve the capability to choose among various contextual factors of a firm, which may affect sustainability of TQM implementation model, and have not been given much consideration in TQM implementation (Shah et al. 2003 cited in Sadikoglu, 2004). The future researches should provide an empiri- 
cal examination of an integration between the successful sustainability of quality, innovation, and knowledge management practices and their impact on the success on sustainable development program using a longitudinal research design.

Fourth, in Indonesia's oil and gas industry, the TQM principles have been implemented since the mid 1980s. In spite of actual utilization of TQM principles in most oil and gas companies, the pros and cons of numerous TQM elements, techniques, and real benefits are still not clearly identified and measured. From this point of view, any future research that might develop a correct measurement instrument and reinforce TQM principles with advanced concepts will be valuable. To date, there have been very few researches aimed at providing empirical evidence of the linkages in the implementation of TQM criteria. This research model is explicitly required in establishing the relations among the various criteria (e.g., QMPs, OE, WCC, CNFP and CFP). This step of study should provide the realization of this research framework that enables researchers and managers to gain an improved insight into the successful sustainability of TQM program by providing a generic framework for TQM implementation model. An empirical test of the linkages among the ten constructs of this research framework can help to provide a roadmap for firms from multiple industries seeking to progress towards total quality cultures and quality of life (Curkovic et al. 2000).

\section{References}

Ahire, S. L., D. Y. Golhar, and M. A. Waller. 1996a. Development and validation of TQM implementation constructs. Decision Sciences 27 (1): 23-56.

American Institute of Certified Public Accountants (AICPA). 1994. Improving Business Reporting-A Customer Focus. New York

Banker, R. D., G. Potter, and D. Srinivasan. 2000. An empirical investigation of an incentive plan that includes nonfinancial performance measures. The Accounting Review 75 (1): 65-92.

Benson, G. P., J. V. Saraph, and R. G. Schroeder. 1991. The effects of organizational context on quality management: An empirical investigation. Management Science 37 (99): 1107-1124.

Bou, J. C., and I. Beltran. 2005. Total quality management, high-commitment human resource strategy and firm performance: An empirical study. Total Quality Management 16 (1): 71-86.

Carpenter, M. A., and Wm.G. Sanders. 2007. Strategic Management: A Dynamic Perspective—Concepts and Cases. Upper Saddle River, New Jersey: Pearson Education, Inc.

Chevron Texaco. 2003. Operational Excellence Practices: Framework and Process Development Guidance. Jakarta.

Cook, L. S., and R. Verma. 2002. Exploring the linkages between quality systems, service quality, and performance excellence: Service providers' perspectives. Quality Management Journal 9 (2): 44-56. 
Curkovic, S., S. Melnyk, R. Calantone, and R. Handfield. 2000. Validating the Malcolm Baldrige National Quality Award framework through structural equation modeling. International Journal of Production Research 38 (4): 765-791.

Dale, B. G. 1994. Quality management system. In B. G. Dale (Ed.) Managing Quality (2 ${ }^{\text {nd }}$ ed.): 333-359. Hemel Hempstead: Prentice Hall.

Dean J. W., and D. E. Evans. 1994. Management theory and total quality: Improving research and practice through theory development. Academy of Management Review 19 (3): 392-418.

Dean, J. W., and D. E. Bowen. 1994. Management theory and total quality: Improving research and practice through theory development. Academy of Management Review 19 (3): 392-418.

Dehning, B., V. J. Richardson, and R. W. Zmud. 2004. The financial performance effects of IT-based supply chain management systems in manufacturing firms. Working Paper, Argyros School of Business and Economics, Chapman University, Orange, CA.

Deloitte Touche Tohmatsu International. 1994. Performance measurement. Working Paper.

Demirbag, M., E. Tatoglu, M. Tekinkus, and S. Zaim. 2006. An analysis of the relationship between TQM implementation and organizational performance: Evidence from Turkish SMEs. Journal of Manufacturing Technology Management 17 (6): 829-847.

Dess, G. 1987. Consencus on strategy formulation and organizational performance: Competitors in a fragmented industry. Strategic Management Journal 8 (3): 259-277.

Dunk. A. S. 2005. Financial and non financial performance: The influence of quality of information system information, corporate environmental integration, and product quality. Advances in Management Accounting 14: 91-114.

Edvinsson, I., and M. S. Malone. 1997. Intellectual Capital: Realizing Your Company's True Value by Finding its Hidden Brainpower. New York: HarperBusiness.

Flynn, B. B., R. G. Schroeder, and E. J. Flynn. 1999. World-class manufacturing: An investigation of Hayes and Wheelwright's Foundation. Journal of Operation Management 17: 249-269.

Gilbert, J. D. 1992. TQM flops: A chance to learn from the mistakes of others. National Productivity Review 11: 491-499.

Hackman, J. R., and R. Wageman. 1995. Total quality management: Empirical, conceptual, and practical issues. Administrative Science Quarterly 40 (1): 309-342.

Hair, J. F., B. Black, B. Babin, R. E. Anderson, and R. L. Tatham. 1998. Multivariate Data Analysis (5 ${ }^{\text {th }}$ ed.). Upper Sadle River, New Jersey: Person Education, Inc.

Hair, J. F., B. Black, B. Babin, R. E. Anderson, and R. L. Tatham. 2006. Multivariate Data Analysis (6 ${ }^{\text {th }}$ ed.). Upper Saddle River, NJ: Person Education, Inc.

Hayes, R. H., and S. C. Wheelwright. 1984. Restoring Our Competitive Edge: Competing Through Manufacturing. New York: John Wiley \& Sons.

Hendricks, K. B., and V. R. Singhal. 2003. The effect of supply chain glitches on shareholder value. Journal of Operations Management 21: 501-522.

Hoskinsson, R. E., M. A. Hitt, W. P. Wan, and D. Yiu. 1999. Theory and research in strategic management: Swings of a pendulum. Journal of Management 25: 417-456.

Ittner, C. D., and D. F. Larcker. 1998. Are non financial measures leading indicators of financial performance? An analysis of customer satisfaction. Journal of Accounting Research 56 (Supplement): 1-35. 
Kaplan, R. S., and D. P. Norton. 1996. The Balanced Scorecard. Boston: Harvard University Press.

Knowledge@Wharton.2000. Non-Financial Performance Measures: What Works and What Doesn't (October 06): 1-4. http://knowledge.wharton.upenn.edu/article.cfm? articleid=279

Kossoff, L. 1993. Total quality or total chaos? HR Magazine 38 (4): 131-134.

Lawrence, P., and J. Lorsch. 1967. Organization and Environment. Boston, MA: Harvard Business School Press.

Leonard, D., and R. McAdam. 2003. An evaluative framework for TQM dynamics in organizations. International Journal of Operations and Production Management 23 (6): 652-677.

Luthans, F., M. J. Rubach, and P. Marsnik. 1995. Going beyond total quality: The characteristics, techniques, and measures of learning organizations. The International Journal of Organizational Analysis 3 (1): 24-44.

McAdam, R. 2000. Three leafed clover: TQM, organizational excellence, and business improvement. The TQM Magazine 12 (5)L: 314-320.

McAdam, R. 2004. Knowledge creation and idea generation: A critical quality perspective. Technovation 24: 697-705.

Melan, E. H. 1998. Implementing TQM: A contingency approach to intervention and change. International Journal of Quality Science 3 (2): 126-146.

Molina, L. M., J. Liorens-Montes, A. Ruiz-Moreno. 2007. Relationship between quality management practices and knowledge transfer. Journal of Operations Management 25: 682-701.

Montes, F. J. I. M., A. V. Jover, and I. M. M. Fernandez. 2003. Factors affecting the relationship between total quality management and organizational performance. International Journal of Quality and Reliability Management 20 (2): 189-209.

Parker, D. N. 1999. Operational Excellence. American Gas 81 (5): 5.

Powell, T. C. 1992. Organizational allignment as competitive advantage. Strategic Management Journal 13 (2): 119-134.

Powell, T. C. 1995. Total quality management as competitive advantage: A review and empirical study. Strategic Management Journal 16 (1): 15-37.

Prajogo, D. I., and A. S. Sohal. 2004b. The multidimensionality of TQM practices in determining quality and innovation performance - An empirical examination. Technovation 24: 443-453.

Prieto, I. M., and E. Revilla. 2006. Learning capability and business performance: A non-fiancial and financial assessment. The Learning Organization 13 (2): 166-185.

Raffio, T. 1992. Delta dental plan of Massachusetts. Sloan Management Review 34: 101-110.

Richardson, H. A., R. J. Vandenberg, T. C. Blum, and P. M. Roman. 2002. Does decentralization make a difference for the organization? An examination of the boundary conditions circumscribing decentralized decision-making and organizational financial performance. Journal of Management 28 (2): 217-244.

Sa, P. E., and A. Abrunhosa. 2007. The role of TQM practices in technological innovation: The Portuguese footwear industry case. Total Quality Management and Business Excellence 18 (1): 57-66.

Sadikoglu, E. 2004. Total quality management: Context and Performance. The Journal of American Academy of Business (September): 364-366. 
Saraph, J. V., P. G. Benson, and R. G. Schroeder. 1989. An instrument for measuring the critical factors of quality management. Decision Sciences 20: 810-829.

Shah, R., and P. T. Ward. 2003. Lean manufacturing: Context, practice bundles, and performance. Journal of Operations Management 21: 129-149.

Sitkin, S. B., K. M. Sutcliffe, and R. G. Schroeder. 1994. Distinguishing control from learning in total quality management: A contingency perspective. Academy of Management Review 19 (3): 537-564.

Skrinjar, R., V. Bosilj-Vuksic, and M. Indihar-Stemberger. 2008. The impact of business process orientation on financial and non-financial performance. Business Process Management Journal 14 (95): 738-754.

Stewart, T. A. 1997. Intellectual Capital: The Wealth of Organizations. New York: Doubleday/Currency.

Tamimi, N. 1995. An empirical investigation of critical TQM factors using exploratory factor analysis. International Journal of Production Research 33 (11): 3041-3051.

Tamimi, N. 1998. A second-order factor analysis of critical TQM factors. International Journal of Quality Science 3 (1): 71-79.

Thompson, A. A., Jr., A. J. Strickland III, and J. E. Gamble. 2010. Crafting and Executing Strategy: The Quest for Competitive Advantage —Concepts and Cases (17 $7^{\text {th }}$ ed.). New York, N.Y.: The McGraw-Hill Companies, Inc.

Ullman, J. B. 2006. Structural equation modeling: Reviewing the basics and moving forward. Journal of Personality Assessment 87 (1): 35-50.

Vancouver, J. B. 1996. Living systems theory as a paradigm for organizational behavior: Understanding humans, organizations, and social processes. Behavior Science 41: 165-204.

Wallman, S. M. H. 1995. The future of accounting and disclosure in an evolving world: The need for dramatic change. Accounting Horizons (September): 81-91.

Wright, P. C., and G. D. Geroy. 2001. Changing the mindset: The training myth and the need for worldclass performance. The international Journal of Human Resource Management: 586-600.

Zink, K. J. 2007. From total quality management to corporate sustainability based on a stakeholder management. Journal of Management History 13 (4): 394-401. 